\title{
真珠岩系人工軽量骨材を用いた高流動コンクリートの フレッシュ性状に関する基礎的研究†
}

\section{Characteristics of Self-Compacting Concrete in Fresh State with Artificial Light-Weight Aggregate}

by

\author{
Koichi KoBayashI *
}

\begin{abstract}
Recently, a new type of artificial light-weight aggregate has been developed. This aggregate has lower water absorption ratio than ordinary light-weight aggregate because of its tight surface structure, and can be used for concrete mixing without pre-wetting procedure. Another advantage of this aggregate is its spherical shape that is expected to increase the fluidity of concrete. In this study, this new light-weight aggregate was applied to self-compacting concrete, and the self-campactability of this concrete was investigated and discussed. The results show that self-compacting concrete with this aggregate has higher self-compactability than that with crushed stone, while the deformation rate of concrete is very small. Segregation between the aggregate and mortar, however, tends to be large because of larger difference of specific gravity between them than in the case of ordinary self-compacting concrete with crushed stone. Increase of unit mass of the light-weight aggregate does not affect so much on self-compactability of concrete. Also, a drop of self-compactability of self-compacting concrete with the light-weight aggregate with the lapse of time after mixing is less than that with crushed stone.
\end{abstract}

Key words : Artificial light-weight aggregate, Self-compacting concrete, Self-compactability, Fresh concrete, Slump flow, Shape of coarse aggregate

\section{1 は じめに}

従来の人工軽量骨材は，連続空隙を有するために吸水 率が極めて大きく, 練り上がったコンクリートのスラン プの低下を防ぐため, あるいはポンプ圧送性を確保する ために，プレウェッティング処理を施すことが一般的で ある。しかしその結果，打設後に骨材中の水がセメント マトリックス内に放出されることにより実質的に高水セ メント比となるため, コンクリートを高強度とすること が困難となり，また凍結融解抵抗性などの硬化後の耐久 性も低下するという面も有する。

そのため, コンクリート構造物の死荷重を軽減できる 等のメリットがあるにもかかわらず，現在では人工軽量 骨材を用いたコンクリートの製造量は非常に小さく, 年 間 80 万 $\mathrm{m}^{3}$ 程度であり, 建築用の生コン, あるいはプレキ ヤストパネル用にわずかに用いられるのみであるのが現状 である. ${ }^{1)}$

一方，近年真珠岩を原材料とし，造粒，焼成した新種 の人工軽量骨材が開発されている.2

この新しい人工軽量骨材は, 焼成時の発泡による空隙 は有するものの, 表面は焼結によって緻密化されており, 従来の人工軽量骨材と比較して吸水率が非常に小さい. したがってミキサ投入前に特別な処理を施さなくても， 一般の砕石等を用いる場合と同様に取り扱うことが可能 であるという特徴を有するため, 上記の従来の人工軽量
骨材が有する短所は解消されるものと期待される.

また, 粒形が球状であることもこの人工軽量骨材の大 きな特徴の一つであり，この骨材を用いたフレッシュコ ンクリートは, 流動, 変形中に批ける粗骨材同士の相互 干渉，噛合いが減少するものと予想される。したがって， 高流動コンクリート用材料として用いた場合, 狭窄部に 打ける閉塞が起こりにくく, 自己充てん性が向上するも のと考えられるが，これまでこの種の人工軽量骨材を高 流動コンクリートに適用した研究例は少ないのが現状で ある.

そこで本研究では，この低吸水率，球状という特徴を 有する新人工軽量骨材を用いた高流動コンクリートの自 己充てん性について調査を行い, 各配合要因が与える影 響について検討し，この骨材の高流動コンクリートへの 適用性について明らかにすることを目的とした。

\section{2 実 験 概 要}

Table Iに本研究で用いた材料の一覧を示す.

ここではセメントは普通ポルトランドセメントを用い たが，混和材としてフライアッシュを併用した。 フライ アッシュは粒子が球状であり，コンクリート用混和材と して用いた場合にはワーカビリティーが改善されるため， これを用いた。 またフライアッシュはポルトランドセメ ントと比較して密度が小さいことから, 軽量骨材とモル タルの密度差を減少させ，粗骨材の分離を低減すること

$\dagger$ 原稿受理 平成 12 年 8 月 23 日 Received Aug. 23, 2000

* 正 会 員 中部大学工学部土木工学科 †487-8501 春日井市松本町, Dept. of Civil Eng., Chubu Univ., Matsumoto-cho, Kasugai, 487-8501 
Table I. Materials.

\begin{tabular}{|c|c|}
\hline Cement & $\begin{array}{l}\text { Ordinary Portland cement; Specific } \\
\text { gravity; } 3.15 \mathrm{~g} / \mathrm{cm}^{3}, \text { Specific surface } \\
\text { area by blaine; } 3260 \mathrm{~cm}^{2} / \mathrm{g}\end{array}$ \\
\hline Fly ash & $\begin{array}{l}\text { Specific gravity; } 2.24 \mathrm{~g} / \mathrm{cm}^{3} \text {, } \\
\text { Specific surface area by blaine; } \\
3680 \mathrm{~cm}^{2} / \mathrm{g}\end{array}$ \\
\hline Fine aggregate & $\begin{array}{l}\text { River sand, Specific gravity; } \\
2.63 \mathrm{~g} / \mathrm{cm}^{3} \text {, Water absorption ratio; } \\
1.63 \% \text {, Fineness modulus; } 2.94\end{array}$ \\
\hline $\begin{array}{l}\text { Coarse aggregate } \\
\text { (crushed stone) }\end{array}$ & $\begin{array}{l}\text { Maximum size; } 15 \mathrm{~mm} \text {, Specific } \\
\text { gravity (saturated and surface-dried } \\
\text { condition); } 2.60 \mathrm{~g} / \mathrm{cm}^{3} \text {, Fineness } \\
\text { modulus; } 6.43 \text {, Percentage of solid } \\
\text { volume; } 63.9 \%\end{array}$ \\
\hline $\begin{array}{c}\text { Coarse aggregate } \\
\text { (light-wight aggregate) }\end{array}$ & $\begin{array}{l}\text { Maximum size; } 15 \mathrm{~mm} \text {, Specific } \\
\text { gravity (absolutely dry condition); } \\
1.15 \mathrm{~g} / \mathrm{cm}^{3} \text {, Fineness modulus; } 6.43 \text {, } \\
\text { Absorption ratio; } 2.5 \% \text {, Solid } \\
\text { content; } 67.0 \%\end{array}$ \\
\hline $\begin{array}{l}\text { High-range water } \\
\text { reducing agent }\end{array}$ & Polycarboxylic acid \\
\hline
\end{tabular}

\section{も使用目的のひとつである.}

またここで用いた人工軽量骨材と最大寸法が同一の砕 石を粗骨材として用いた高流動コンクリートも練り混ぜ, 人工軽量骨材を用いた場合との比較を行った。

砕石は表乾状態にして用いたが，人工軽量骨材は絶乾 状態で用いた。本研究で用いた人工軽量骨材は, 既に述 べたように, 従来の人工軽量省材と比較して吸水量が小 さいのが特徴では西るが，本来は只の含水量を把握し， 練混ぜ時に投入する水量を調整して用いるのが望ましい. しかし，生コンプラント等でこの骨材を用いたコンクリ 一トを製造する際に，別の貯蔵サイロを新たに準備する ことは困難であり，実際には気乾状態で用いられること が多いと考光られるため，ここでは絶乾状態にして骨材 の含水量の調整を行なわずに用いた。また本研究では配 合表に打ける人工軽量骨材の単位量は全て絶乾質量であ り，碑石に関しては表乾質量を示した。

練混ぜは，水䄧よび高性能 $\mathrm{AE}$ 減水剂以外の材料をミ キサに投入し 30 秒間の空練りを行なった後に, 水拉よ び高性能 $\mathrm{AE}$ 減水㓱を投入し，さらに 90 秒間練り混ぜ た。炎の後 5 分間静置した後に 30 秒間練り混ぜ、コン クリートをミキサから排出した。また練混ぜは室温下の 実験室にて行なった。

高流動コンクリートのスランプフロー試験，充てん装 置を用いた間げき通過性試験を土木学会規準 (JSCE-F
511）に従って行った。スランプフロー試験時には，スラ ンプフロー $500 \mathrm{~mm}$ 到達時間の测定も行った。間げき通 過性試験はボックス型充てん装置および R1 障害（鉄筋 間距離はすべて $35 \mathrm{~mm}$ ）を用いて自己充てん性の判定を 行なった。

また, 間げき通過性試験が終了し, 試料の流動が静止 してから 3 分程度静置した後に, 試験器の試料投入側, 流出側の气れぞれ最上部からコンクリートを 1.3 リット ルずつ採取し (Fig. 1参照)，5mm ふるるいを用いたウエ ットスクリーニングにより，採取した試料から粗骨材の 多を取りだした後，粗骨材を表乾状態にして只の質量を 測定した。

さらに, 各コンクリートのモルタル分と同一配合のモ ルタルを, 別途モルタルミキ步にて練り混ぜ，囘転粘度 計にてこれらモルタルの降伏值および塑性粘度の測定を 行った。

\section{3 結果および考察}

$3 \cdot 1$ 配合の選定

まず，10パッチ程度の試し練りにより配合を抢打よそ 決定した後に, Table Iに示す範囲の配合のコンクリー 卜を 20 配合程度練り混ぜた。

これら Table IIに示した人工軽量骨材を用いた高流動 コンクリートに扔ける，スランプフローと間げき通過性 試験による自己充てん高さの関係を Fig. 2 に示す。

ここでは単位水量が $144 \mathrm{~kg} / \mathrm{m}^{3}$ でスランプフローが $530 \mathrm{~mm}$ 程度の配合以外は，いずれも自己充てん高さは $300 \mathrm{~mm}$ 以上となった。間げき通過性試験装置の流動障

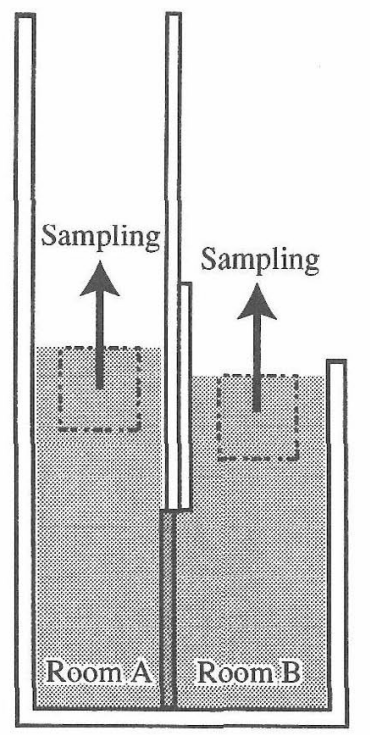

Fig. 1. Sampling of concrete from box apparatus.

Table II. Mixtures for trials.

\begin{tabular}{c|c|c|c|c|c|c}
\hline \multirow{2}{*}{$\begin{array}{c}\text { W/B } \\
(\%)\end{array}$} & \multirow{2}{*}{$\begin{array}{c}\text { s/a } \\
(\%)\end{array}$} & \multirow{2}{*}{$\begin{array}{c}\text { Gvol. } \\
\left(\mathrm{m}^{3} / \mathrm{m}^{3}\right)\end{array}$} & \multicolumn{3}{|c|}{ Unit mass $\left(\mathrm{kg} / \mathrm{m}^{3}\right)$} & $\mathrm{B} \times(\%)$ \\
\cline { 4 - 7 } & & $\mathrm{W}$ & $\mathrm{C}$ & $\mathrm{Fa}$ & $\mathrm{SP}$ \\
\hline $28.2 \sim 29.1$ & $44.3 \sim 50.2$ & $0.308 \sim 0.342$ & $144 \sim 148.5$ & 265 & 245 & $1.5 \sim 1.8$ \\
\hline
\end{tabular}




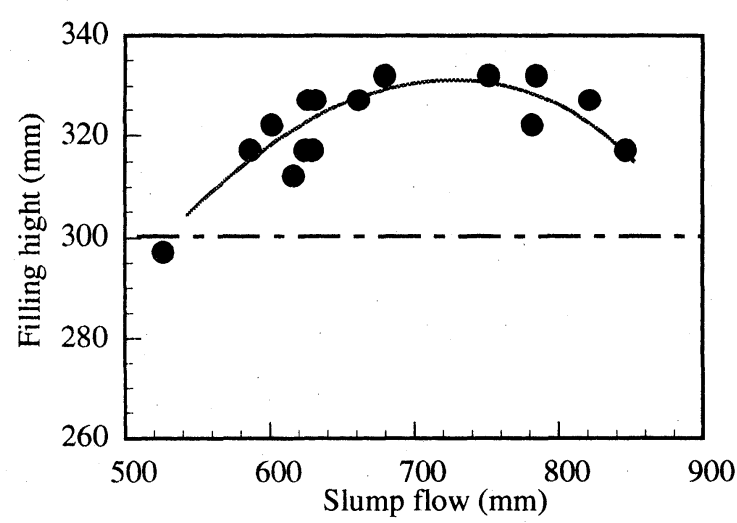

Fig. 2. Relationship between slump flow and filling height in box apparatus.

害は，条件の厳しい R1 障害を用いているが，ここで検 討した人工軽量骨材は最大寸法が $15 \mathrm{~mm}$ であり，一般の 場合と比較して若干小さい. したがって骨材の最大寸法 に対する流動障害の鉄筋間隔の比率が大きいため，その 影響に関しては別途検討する必要があるものと考えられ るが，少なくとも通常の間げき通過性試験装置を用いた 場合には，ほとんどの配合が良好な自己充てん性を有す ると判定される結果となった。

しかし，なかにはスランプフローが $800 \mathrm{~mm}$ 以上とな り, 一般的に高流動コンクリートが良好な自己充てん性 を有する目安として考えられているスランプフロー 600 〜 700mm を大幅に逸脱しているものもあった．また， このような配合はスランプフロー試験時に，流動先端付 近に打いて目視により分離が認められた。

逆にスランプフローが $600 \mathrm{~mm}$ 以下でも, 自己充てん 高さが $300 \mathrm{~mm}$ 以上と, 良好な自己充てん性を示す配合 もあった。この場合には, 通常の高流動コンクリートと 比較して見掛けの流動性が小さいにも関わらず, 粗骨材 の形状が球形に近いため, 鉄筋間を透過する際の粗骨材 同士の噛合わせが減少し，優れた自己充てん性を有して
いるものと考えられる。また後述するように，コンクリ 一トの密度が小さいために, 同程度の軟度を有する一般 の高流動コンクリートと比較して, スランプフローが小 さくなることも原因として考えられる.

\section{$3 \cdot 2$ 間げき通過性試験後の粗骨材濃度による評価}

前項で述べたように，スランプフロー試験時に流動 先端付近で分離が観察されたコンクリートの場合におい ても, 自己充てん高さが $300 \mathrm{~mm}$ 以上となる例が観察さ れた。

一般の砕石を用いた高流動コンクリートの場合には， 分離が生じることにより粗骨材が沈降し，間げき通過性 試験装置内の鉄筋間で閉塞が生じるため，このようなコ ンクリートは充てん高さが低くなり，自己充てん性が低 いと判定される結果となる.

一方，軽量骨材を用いた場合には，粗骨材とモルタル との間に分離が生じると, 両者の密度差により粗骨材は 浮上するため, 粗骨材濃度が低いコンクリートが間げき 通過性試験装置の鉄筋障害間を透過することになり，分 離が生じた場合の方が自己充てん高さが大きくなること も考えられる。したがって，間げき通過性試験における 自己充てん高さのみからではコンクリートの分離を正確 に判定することができないと考えられる.

そこで，2 章で述べたような方法で，間げき通過性試 験実施後に試験器の試料投入側および流出側の粗骨材量 を測定し，コンクリート中に占める粗骨材の体積濃度を 算出して評価を行った.

軽量骨材を用いた高流動コンクリートのスランプフロ 一，あるいはスランプフロー $500 \mathrm{~mm}$ 到達時間と間げき 通過性試験後の試料投入側 (Room A), 流出側 (Room B) における粗骨材体積濃度との関係を Fig. 3 に示す. なお図中で直線で結ばれたデータは, 同一のコンクリー トにて得られたデータであることを示し，さらにここで の平均濃度は, 示方配合から算出した表乾状態における 理論上の粗骨材体積濃度である。
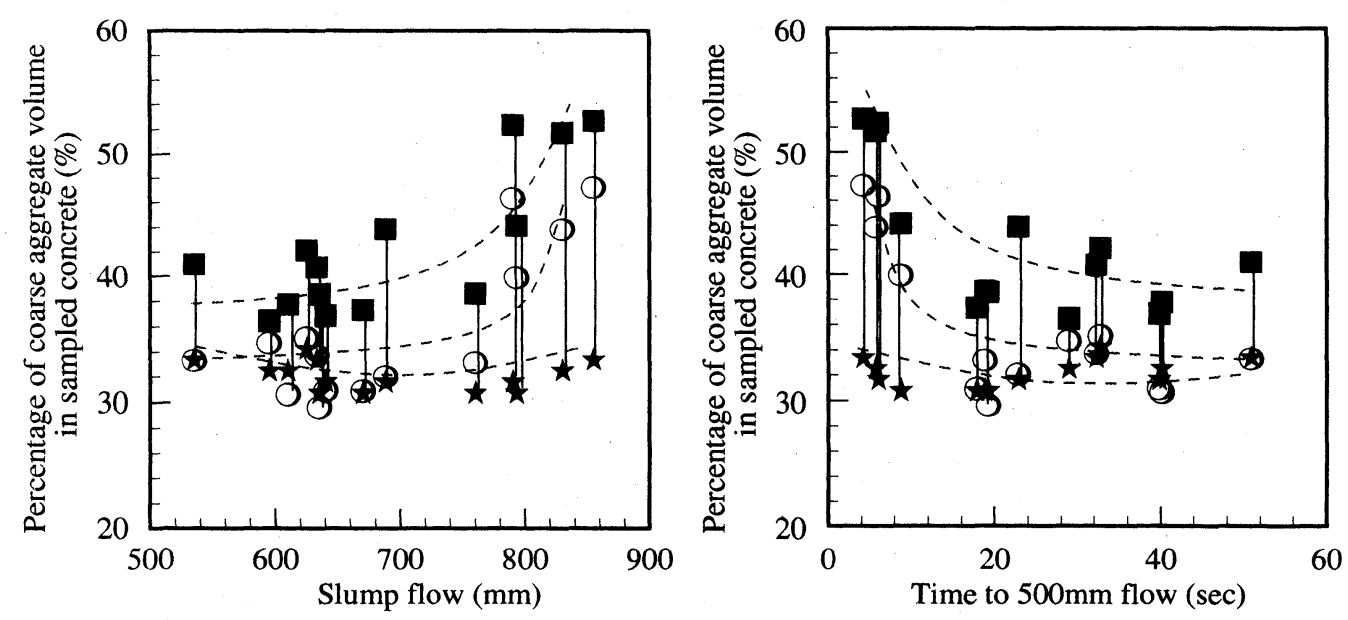

Room A $\bigcirc$ Room B $\quad \star$ Average (theoretical)

Fig. 3. Relationship between aggregate volume in concrete sampled from box apparatus and slump flow or time to $500 \mathrm{~mm}$ flow. 
またここではスランプフローが $530 \mathrm{~mm}$ 程度の 1 配合 を除いて, いずれも間げき通過性試験による自己充てん 高さは $300 \mathrm{~mm}$ 以上である.

軽量骨材を用いたコンクリートは, 自己充てん高さが $300 \mathrm{~mm}$ 以上であっても分離が生じ, モルタルよりも密度 が小さい人工軽量骨材の浮上が著しい場合があり, 粗骨 材の平均濃度が $30 \%$ 強程度であるのに対し, 間げき通過 性試験後に試験器上部から採取した試料の粗骨材体積濃 度が $50 \%$ をこえものもあった。

一方ここでは図示していないが，後述する砕石を用い た高流動コンクリートで自己充てん高さが $300 \mathrm{~mm}$ 以上 となる配合の場合には, 理論上の平均濃度が $30.77 \%$ であ るのに対し, 試料投入側, 流出側ともに粗骨材濃度は $25.7 \sim 29.5 \%$ と理論値より小さかった. モルタルよりも 密度の大きな砕石は沈降するためで, また試験器上部に おける骨材濃度と平均濃度との差は人工軽量骨材を用い た場合と比較して小さくなった。

砕石を用いた通常の高流動コンクリートの場合にもス ランプフローが $700 \mathrm{~mm}$ 以上となると, 一般に分離が生 じ，自己充てん性が低下することが知られているが，人 工軽量骨材の場合にもスランプフローが $700 \mathrm{~mm}$ 以上の 場合には, 試験後に採取した試料中の粗骨材体積濃度が 非常に大きくなる傾向にあった.

一方，人工軽量骨材を用いても，スランプフローが $700 \mathrm{~mm}$ 程度以下の場合には，充てん装置の流出側にお いては粗骨材体積濃度はほほ理論值に等しくなった。 そ の場合にも，充てん装置の試料投入側に打ける粗骨材体 積濃度は, 本研究で検討した最も小さなスランプフロー の配合においても完全に理論値と一致させることは困難 で, 理論値よりも $3 \sim 8 \%$ 程度大きくなっているが, 一 応スランプフロー $700 \mathrm{~mm}$ 程度以下を分離が小さくなる 目安とすることができるものと考えられる。

柳井らは, 絶乾密度が $0.94 \mathrm{~g} / \mathrm{cm}^{3}$ と本研究のものより も若干小さな真珠岩系人工軽量骨材を用いた場合, 同一 水結合材比で粗骨材濃度が $0.270 \sim 0.400 \mathrm{~m}^{3} / \mathrm{m}^{3}$ の範囲 の高流動コンクリートの圧縮強度はほぼ同一で, ヤング 率と粗骨材濃度の間にも明確な関係は見られなかったこ とを報告している。昼したがって，ここで示したスランプ フロー 700mm 以下の範囲においては, 硬化コンクリー トの性状はそれほど相違しないものと考えられる。

また，モルタル部の密度が $2.2 \sim 2.3 \mathrm{~g} / \mathrm{cm}^{3}$ であるのに 対し, 砕石の密度は $2.60 \mathrm{~g} / \mathrm{cm}^{3}$, 人工軽量骨材の密度は $1.15 \mathrm{~g} / \mathrm{cm}^{3}$ で, 人工軽量骨材はモルタルとの密度差が非 常に大きいため，これを用いた場合には分離が大きくな
ったと考えられる。したがって粗骨材の分離，上昇を小 さくするためには, モルタルの降伏值を所定の流動性, 自己充てん性が得られる範囲で，できるだけ大きくする 必要があるものと考えられる。

以上の検討結果から, 良好な自己充てん性を有し, ま た比較的粗骨材の分離が少ない配合を選定し，基本配合 とすることとした (Table III).

また本節の結果より，これ以降用いる高流動コンクリ 一トのスランプフローは，すべて $700 \mathrm{~mm}$ 以下とした。 そ の結果, 間げき通過性試験終了後に試験器の試料投入側 から採取したコンクリートの粗骨材濃度と示方配合から 算出した理論値との差は 7\% 以下, 流出側から採取した コンクリートの粗骨材濃度と理論值との差は $5 \%$ 以下で あったため，いずれも材料分離は許容範囲以下であると 判断した.

\section{$3 \cdot 3$ 砕石を用いた場合との比較}

Table III に示した人工軽量骨材高流動コンクリート， およびこの配合と単位セメント量, 単位混和材量, 単位 混和剤量, および単位粗骨材体積が同一の, 砕石を用い た高流動コンクリートを練り混ぜ，比較を行った。

人工軽量骨材を用いた場合と同一の単位水量とする と，砕石を用いた場合にはスランプフロー，流動速度が 小さく，自己充てん高さも $300 \mathrm{~mm}$ 以下となったため， Fig. 4 に示すように単位水量を $147 \mathrm{~kg} / \mathrm{m}^{3}$ から $150 \mathrm{~kg} /$ $\mathrm{m}^{3}$ まで $1 \mathrm{~kg} / \mathrm{m}^{3}$ 刻みで増し，水の増量分は同体積の細骨 材を減じて配合を調整した。

その結果，砕石を粗骨材として用いた場合には，単位 水量を $1 \sim 2 \mathrm{~kg} / \mathrm{m}^{3}$ 程度増量することによって, 人工軽 量骨材を用いた場合と同程度の流動性, 自己充てん性が 得られるようになった.

小門らによれば，コンクリートの降伏值はスランプフ ローの 5 乗に逆比例し, コンクリートの密度に比例する. したがって，コンクリートのスランプフローがその自重 による変形であることを考えれば，密度のみが砕石と異 なり, 粒径, 粒形等, 他の品質は全く同一の軽量骨材を 用いると仮定すると， スランプフローは砕石を用いたも のより小さな值になるものと考えられる.

一方，スランプフローがほぼ同じである人工軽量骨材 を用いた $W=147 \mathrm{~kg} / \mathrm{m}^{3}$ の配合と, 砕石を用いた $W=$ $148 \sim 150 \mathrm{~kg} / \mathrm{m}^{3}$ の配合を比較すると, 前者の方が単位 水量が小さいためにモルタルの降伏值が大きく, 流動性, 変形性能は小さいと考えられるのにもかかわらず，使用 した骨材の密度差を考慮すると, コンクリートの降伏值 は小さいことになる。

Table III. Standard mixture in this study with light-weight aggregate.

\begin{tabular}{c|c|c|c|c|c|c|c}
\hline \multirow{2}{*}{$\begin{array}{c}\text { W/B } \\
(\%)\end{array}$} & \multirow{2}{*}{$\begin{array}{c}\text { s/a } \\
(\%)\end{array}$} & \multicolumn{5}{|c|}{ Unit mass $\left(\mathrm{kg} / \mathrm{m}^{3}\right)$} & $\mathrm{B} \times(\%)$ \\
\cline { 3 - 8 } & & $\mathrm{W}$ & $\mathrm{C}$ & $\mathrm{Fa}^{*}$ & $\mathrm{~S}$ & $\mathrm{G}$ & $\mathrm{SP}$ \\
\hline 28.8 & 50.0 & 147 & 265 & 245 & 811 & 354 & 1.6 \\
\hline
\end{tabular}



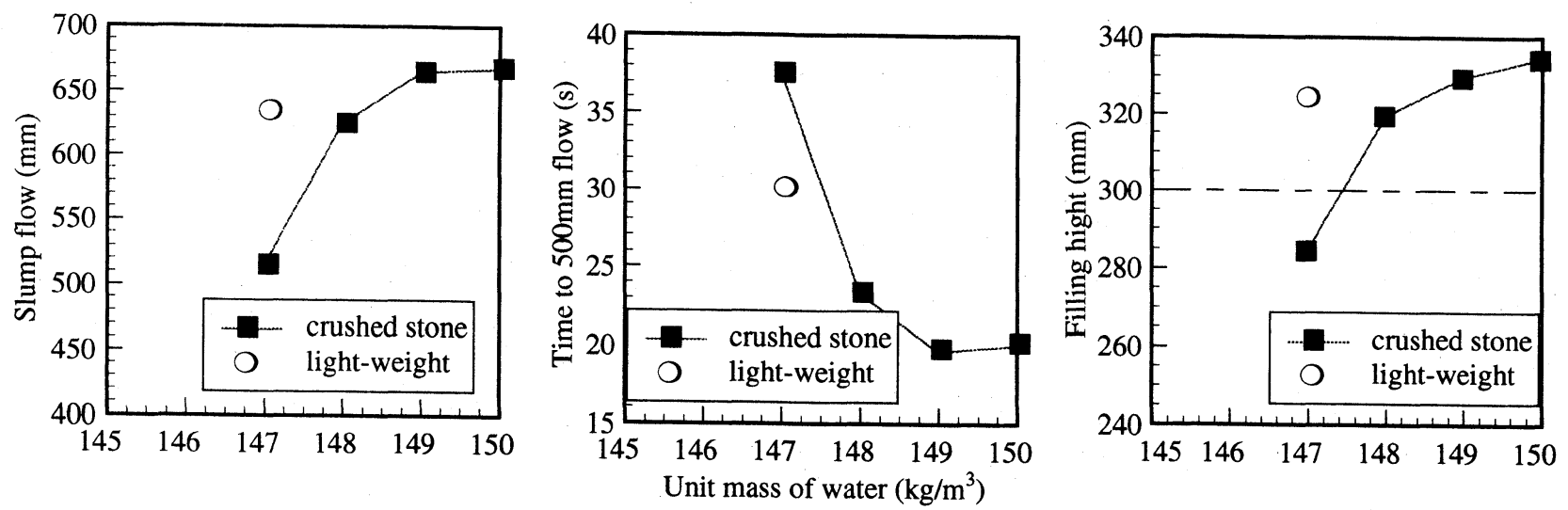

Fig. 4. Comparison of characteristics of fresh concrete with light-weight aggregate and with crushed stone.

従来，川砂利の使用によってコンクリートの流動性が 向上することが知られている. ${ }^{7)}$ 本研究で用いた人工軽量 骨材は形状が球に近いため, フレッシュコンクリート中 での骨材同士の相互干渉と云った観点から考えれば，砕 石よりも川砂利に近い挙動を示すものと考えられる。兄 のため，より少ない単位水量でもフレッシュコンクリー トの流動性が大きくなったものと考えられる.

また，コンクリートのスランプフロー $500 \mathrm{~mm}$ 到達時 間と, 別途練り混ぜたモルタルの塑性粘度との関係を Fig. 5 に示す．ただし，ここでは間げき通過性試験によ る自己充てん高さが $300 \mathrm{~mm}$ 以上で，かつ前節に扔いて 比較的分離が小さいと判断された配合のみを対象として いるが，コンクリートのスランプフローの範囲が大きい ため, スランプフローを $500 \mathrm{~mm}$ で除した值を 2 乗し，ス ランプフロー $500 \mathrm{~mm}$ 到達時間に乗ずることによって補 正した值を用いている.

Fig. 4 の単位水量とスランプフロー $500 \mathrm{~mm}$ 到達時間 の関係によれば，スランプフロー, 自己充てん高さの場 合と比較して, 粗骨材の相違による流動速度の差は比較 的小さい．また, Fig. 5 のように，スランプフローの大 小によるスランプフロー $500 \mathrm{~mm}$ 到達時間の補正を行え ば，むしろ人工軽量骨材を用いた高流動コンクリートの 方が流動速度は小さくなる。

また Fig. 5 によれば, コンクリートの流動速度とモル タルの塑性粘度の間には明確な関係は見られないものの, モルタルの塑性粘度が同程度であっても, 人工軽量骨材 を用いたものは流動速度が小さく，コンクリートの見掛 けの塑性粘度が大きいことがわかる。これは人工軽量骨 材コンクリートの密度が小さいために, スランプフロー 流動時に自重の作用が小さくなり, 変形速度も小さくな るためであると考えられる.

前述の降伏值と同様に, 川砂利を用いたコンクリート は砕石を用いたコンクリートよりも塑性粘度が小さく, ス ランプフロー速度も大きくなることが報告されている. したがって,ここで用いた人工軽量骨材のように粒型か球 状であることは高流動コンクリートの見掛けの塑性粘度 を小さくする方向に作用すると考えられるが，実際には川 砂利と異なり密度が小さいことによる影響が卓越し，

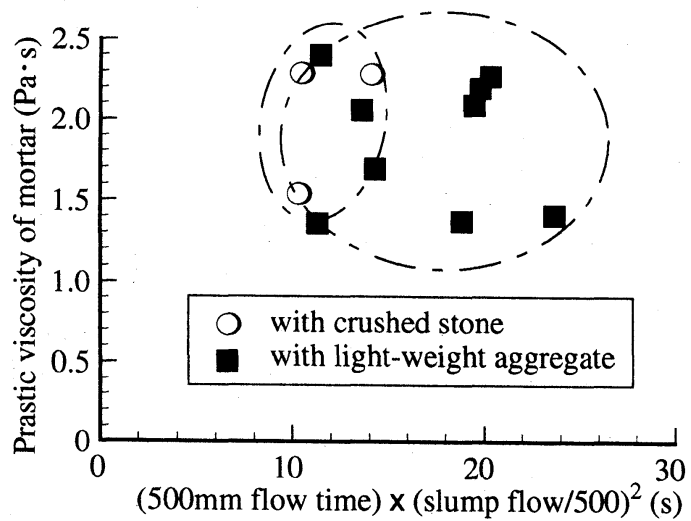

Fig. 5. Relationship between $500 \mathrm{~mm}$ flow time of concrete and plastic viscosity of mortar.

Fig. 5 に示すような結果が得られたものと考えられる.

また，ここでは人工軽量骨材は絶乾状態で用いている ため，表乾状態で用いた場合には，同程度の流動性，自 己充てん性を得るために必要な単位水量の，砕石を用い た場合と人工軽量骨材を用いた場合の相違は，さらに大 きくなるものと考えられる.

\section{$3 \cdot 4$ 粗骨材量の影響}

ここまでの検討結果から，粗骨材の形状の違いが高流 動コンクリートの流動性, 自己充てん性に大きく影響を 与えていることが推察された。一般に，高流動コンクリ 一トの配合設計を行う場合, コンクリート中の粗骨材体 積濃度を粗骨材の実績率の $1 / 2$ 以下にしなければ，鉄筋 障害間通過の際に閉塞が生じるとされて抢り ${ }^{10}$ )また高流

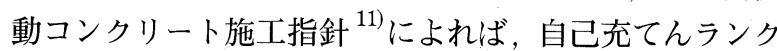
1 の高流動コンクリートの場合には，さらに粗骨材量を 減じる必要があるとされている.

そこで，単位粗骨材量あるいは粗骨材体積濃度がフレ ッシュコンクリートの性状に与える影響について検討す ることとした。

ここで検討を行ったのは, Table IIIに示した人工軽量 骨材を用いた高流動コンクリートの基本配合をもとにし， 細骨材量を減じて, 粗骨材量を $354 \mathrm{~kg} / \mathrm{m}^{3}$ から $424 \mathrm{~kg} /$ $\mathrm{m}^{3}$ まで増加させた配合であり (Table IV)，コンクリート 
Table IV. Mixtures for investigation for effect of unit mass of light-weight aggregate.

\begin{tabular}{|c|c|c|c|c|c|c|c|c|}
\hline \multirow{2}{*}{$\begin{array}{l}\text { W/B } \\
(\%)\end{array}$} & \multirow{2}{*}{$\begin{array}{l}\mathrm{s} / \mathrm{a} \\
(\%)\end{array}$} & \multirow{2}{*}{$\begin{array}{l}\text { Gvol. } \\
\left(\mathrm{m}^{3} / \mathrm{m}^{3}\right)\end{array}$} & \multicolumn{5}{|c|}{ Unit mass $\left(\mathrm{kg} / \mathrm{m}^{3}\right)$} & \multirow{2}{*}{$\frac{\mathrm{B} \times(\%)}{\mathrm{SP}}$} \\
\hline & & & $\mathrm{W}$ & $\mathrm{C}$ & $\mathrm{Fa} *$ & $S$ & G & \\
\hline 28.8 & $40.1 \sim 50.0$ & $0.308 \sim 0.369$ & 147 & 265 & 245 & $649 \sim 811$ & $354 \sim 424$ & 1.6 \\
\hline
\end{tabular}

中の粗骨材濃度が $30.8 \sim 36.9 \%$ の場合に相当する.

人工軽量骨材を用いた場合に単位粗骨材量がコンク リートのフレッシュ性状に与える影響について Fig. 6 に 示す.

単位粗骨材量の増加によって，スランプフロー $500 \mathrm{~mm}$ 到達時間については 25 秒から 40 秒の範囲で大幅に変化 したが，スランプフロー, 自己充てん高さにはほとんど 変化が見られなかった。

ここで検討した粗骨材濃度の最大值は $36.9 \%$ であり， 人工軽量骨材の実積率 $67.0 \%$ の $1 / 2$ を大きく上回ってい るにもかかわらず，良好な自己充てん性が得られている. これは既に述べたように，骨材の形状が球形に近いため に,コンクリートの流動中における粗骨材同士の相互干 渉が低減されているためであると考えられる.

また，粗骨材の相互干渉はモルタルの粘性を大きくす ることによって低減されることも報告されている. ${ }^{10)}$ しか し，人工軽量骨材を用いた場合には，コンクリートの流 動速度が小さく，コンクリートの見掛けの粘度は大きい ものの, Fig. 5 より砕石を用いた配合と人工軽量骨材を 用いた配合でモルタル部の塑性粘度に大差ないことは明 らかである。したがって，両骨材を用いたコンクリート の自己充てん性が異なるのは，粘性の相違によるとは考 えにくく，粒形の相違が大きな影響を与えているものと 考えられる。

一方，ここでは間げき通過性試験時に条件のより厳し いR1 障害を用いてはいるが，人工軽量骨材の最大寸法 が $15 \mathrm{~mm}$ と，通常の場合よりも小さく，また細骨材量の 減少させていることよりモルタル性状も変化していると 考えられるため，これらの影響も今後検討する必要があ るものと考えられる。

\section{$\mathbf{3} \cdot \mathbf{5}$ 練混ぜ後の経過時間が与える影響}

本研究で用いた人工軽量骨材は, 従来の人工軽量骨材 と比較して吸水率が小さく, プレウェッティングの必要 がないことが大きな特徵の一つであり，また実施工に用 いる場合には，プラントの設備の関係もあり，この特徴 を生かして，気乾状態で用いられることが多いものと予 想される。しかし，高流動コンクリート用材料として用 いた場合には，粗骨材の吸水により流動性等のフレッシ ユ時の品質が低下することが懸念される。

そこで，Table IIIに配合を示した単位水量 $147 \mathrm{~kg} / \mathrm{m}^{3}$ の人工軽量骨材を用いた高流動コンクリート，および前 節の検討結果から，Table IVの砕石を用いた高流動コンク リートのうち単位水量を $150 \mathrm{~kg} / \mathrm{m}^{3}$ とした配合を練り混 ぜ，スランプフロー，スランプフロー $500 \mathrm{~mm}$ 到達時間， 自己充てん高さの経時変化を測定し，Fig. 7 に示す.

いずれの粗骨材を用いても，スランプフローは時間の 経過とともに低下し，使用粗骨材による差はそれほど大 きくない。

それに対し，スランプフロー $500 \mathrm{~mm}$ 到達時間は，人 工軽量骨材を用いたものの方が大きく，また使用骨材の 違いによる差も時間の経過とともに大きくなっている. 特に練り混ぜ後 90 分経過した後には，人工軽量骨材を 用いた配合のスランプフロー $500 \mathrm{~mm}$ 到達時間は，60 秒 以上にもなっている。にもかかわらず，人工軽量骨材を 用いた配合は，練り混ぜ後 120 分までは間げき通過性 試駼装置による自己充てん高さが $300 \mathrm{~mm}$ 以上となって いる.

ここでは碀石は表乾状態で，人工軽量骨材は絶乾状態 にて用いているため, 人工軽量骨材を用いた配合は粗骨 材の吸水により流動性および自己充てん性の低下が大き
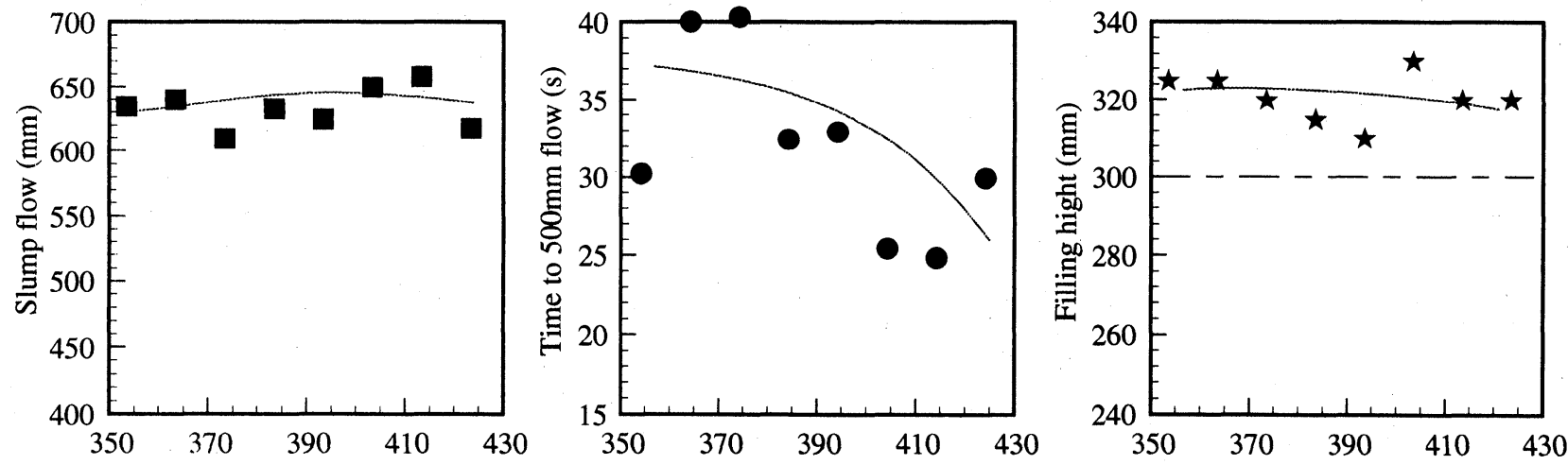

Unit mass of light weight aggregate $\left(\mathrm{kg} / \mathrm{m}^{3}\right)$

Fig. 6. Effects of unit mass of light-weight aggregate on characteristics of fresh concrete. 

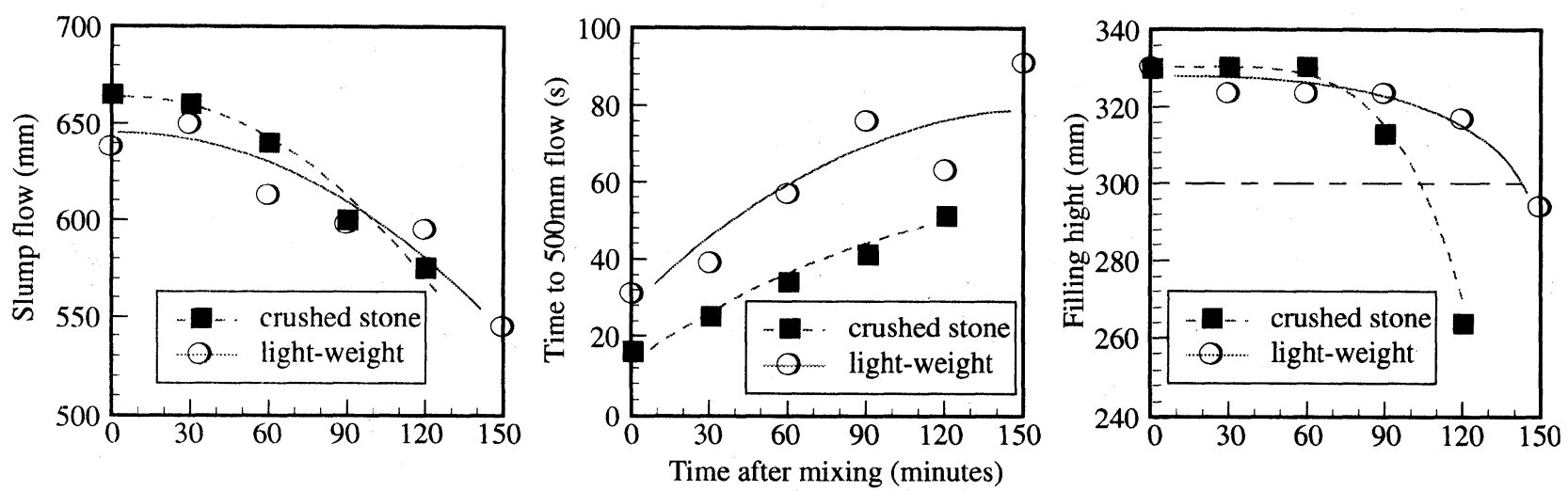

Fig. 7. Effects of time after mixing on characteristics of fresh concrete.

いことが予想され，実際にスランプフロー $500 \mathrm{~mm}$ 到達 時間の低下は人工軽量骨材を用いた配合の方が大きかっ た。にもかかわらず高流動コンクリートにとって最も重 要な品質である自己充てん性の低下は，人工軽量骨材を 用いた配合の方が小さいという結果となった。

砕石を用いた高流動コンクリートは，骨材の噛合わせ が生じやすい状況にあるために，閉塞を生じないために は粗骨材がある程度以上の運動エネルギー，すなわち変 形速度を有する必要があるため，スランプフローの低下 で表現される降伏値の増大による自己充てん性の経時変 化が大きいものと考えられる，逆に人工軽量骨材を用い たコンクリートは, 粗骨材が球状であるため, 流動性が 低下して粗骨材の運動エネルギーが小さくなっても，自 己充てん性が保持されるものと考えられる.

しかし，ここでの人工軽量骨材を用いた高流動コンク リートのように, 極めて変形速度の小さなコンクリート は，施工速度が著しく劣り，ポンプ圧送も困難であるも のと考えられる。したがって，施工時には練混ぜから打 設までの時間に応じて軽量骨材の含水率を考慮して単位 水量を調整する，あるいはバケット打ちを採用する等の 対策を行なうことが必要であると考えられる。

\section{4 結 論}

本研究では，新たに開発された真珠岩系の人工軽量骨 材を用いた高流動コンクリートのフレッシュ性状に関し て，基本的な検討を行った.

その結果，人工軽量骨材を用いた高流動コンクリート に関して，以下のような結果が得られた。

(1) 広い範囲のスランプフローに対して良好な自己充 てん性を有する.

（2）ただし間げき通過性試験の結果が良好であっても 粗骨材の分離, 浮上が生じている場合がある.

（3）同一の単位水量で砕石を用いた配合と比較して, 自己充てん性は大きい.

（4）単位粗骨材量が増加しても自己充てん性の低下に 与える影響は小さい。
（5）練混ぜ後の時間経過にともなう自己充てん性の低 下は小さい.

今後の課題としては，フロー速度が小さいことから， ポンプ圧送性などの施工性に関する検討を行う必要があ るものと思われる.

人工軽量骨材は太平洋セメント(株), 混和剤は(株)エヌエ ムビーからご提供いたたいた。 また害験の遂行には奥村 幸生, 古崎高行, 澤井淳の各氏（当時, 小林研卒研生） の協力をいただいた。ここに記して謝意を表する.

\section{参 考 文 献}

1) 岡本享久, 早野博幸, 柴田辰正, コンクリート工学, 361, 48 (1998).

2 ) 岡本享久, 石川雄康, 栩木 隆, 笹嶋昌男, コンクリート 工学, 37-4, 12 (1999).

3 ）柳井修司, 坂田 昇, 渡邊賢三, 信田佳延, コンクリート 工学年次論文報告集, 21-2，337（1999）。

4) 野上良浩, 柳井修司, 坂田 昇, 岡本享久, 丸山久一, 土木学会第 54 回年次学術講演会講演概要集, V, 294 (1999).

5 ) 小門 武, 宮川豊章, 土木学会論文集, 634/V-45, 113 (1999).

6) 柳井修司, 坂田 昇, 信田佳延, 岡本享久, 土木学会論 文集，648/V-47, $23(2000)$.

7 ) 高野 肇, 和美廣喜, 炭村栄一, 矢内雅之, 湯浅 昇, 笠井芳夫, 日本建築学会大会学術講演梗概集， A，941 (1992).

8）塩見伊津夫, 桝田佳寞, 阿部道彦, 安田正雪, 松本雅之, 日本建築学会大会学術講演梗概集, A, 797 (1991).

9) 北村昌彦, 田中. 勲, 鈴木信雄, セメント・コンクリート 論文集，45，172（1991）。

10）岡村 甫, 前川宏一, 小澤一雅, “ハイパフォーマンスコ ンクリート”, p.7（1993）技報堂出版。

11）土木学会，高流動コンクリート施工指針（1998）. 